\title{
ЯЗЫКОЗНАНИЕ
}

\author{
А.А. Левдик
}

\section{СПЕЦИФИКА ВЕРБАЛИЗАЦИИ ФРЕЙМА «ОБРАЗОВАНИЕ» В СОСТАВЕ СЦЕНАРИЯ «КАРЬЕРА» В РАМКАХ РУССКОЙ КАРТИНЫ МИРА}

Аннотация. В настоящей статье автор подробно рассматривает специфику развития сценария «карьера» в рамках структурирования фрейма «Образование» на соответствующие информационные блоки, содержащие данные о конкретной ситуации. Актуальные данные представлены с позиции лексико-семантического анализа языковых единиц, отношения между которыми обуславливают динамику развития сценария. Следует отметить, что фреймовое представление знаний конкретного языкового сообщества относительно в силу проведения анализа, за основу которого был взят материал автобиографических трудов и мемуаров выдающихся русскоязычных личностей. Методом исследования в данной статье выступает лексико-семантический анализ высказываний, являющихся материалом текстов мемуаров и автобиографий известных русскоязычных личностей. Основным выводом проведенного исследования является отображение динамики развития сценария внутри анализируемого фрейма при переходе от одного этапа (слота) к другому со связывающими их отношениями. Поэтому тщательный лексико-семантический анализ позволяет выделить культурную составляющую с целью ее последующего изучения. Результаты подобного исследования представляются особенно важными для проведения лингвокультурологического исследования.

Ключевые слова: сценарий, фрейм, слот, лексема, когнитивный, репрезентация, вербализация, слотовая наполняемость, карьера, образование.

Abstract. In the present article the author examines distinguishing features of the development of the 'Career' scenario within the 'Education' framework structure depending on certain information blocks containing data about a particular situation. Relevant data are presented from the point of view of the lexical semantic analysis of linguistic units which relations determine the dynamics of the scenario development. It should be noted that the frame-based representation of knowledge in a particular linguistic community has a relative nature due to the analysis being based on autobiographic materials and memoirs written by famous Russian-speaking figures. The research method used by the author of the article is the lexical semantic analysis of expressions from memoirs and autobiographies of famous Russian-speaking figures. The main conclusion of the research is the author's description of the development dynamics of the scenario within the analyzed framework at the moment of the transfer from one stage (slot) to another stage and associated relations between these stages. Detailed lexical semantic analysis allows to define the cultural component that can be further studied. The results of the research are of special importance for linguoculturological research.

Key words: scenario, framework, slot, lexical unit, cognitive, representation, verbalization, slot occupancy, career, education.

Д

ля создания достоверной модели определенного сценария необходимо раскрыть содержание входящих в него и, следовательно, определяющих его содержание, составных частей. Преобладание или отсутствие конкретных элементов обусловлено главным образом лингвокультурными различиями. В нашем исследовании мы опираемся на работы по исследованию сценарных структур. Так, например, Мамина Т.В. рассматривает специфику лингвокогнитивного моделирования сценария «карьера»в русском языке, в рамках которого автор проводит исследование данного концептуального образования на материале корпуса текстов русского языка. В нашем случае практическим материалом выступают мемуары, автобиографии людей, получивших широкую известность благодаря достижениям в той или иной сфере деятельности.

Материалом для исследования послужили мемуары таких выдающихся личностей как: Жуков Г.В., Путин В.В., Кобзон И.Д., Королев С.П., Яшин Л. И. Каждый из них построил блестящую карьеру в сфере своей профессиональной деятельности. Карьера, по определению, зафиксированном в Толковом 
словаре С.И.Ожегова, Н.Ю.Шведовой, представляет собой род занятий, деятельности; путь к успехам, видному положению в обществе, на служебном поприще, а также само достижение такого положения. Ключевым является слово «путь» [6]. Вследствие этого, карьера представляется нам как явление, отмеченное не только темпоральными характеристиками, но и сменяющими друг друга этапами с присущими им определенной динамикой развития.

Для построения сценария «карьера» необходимо представить систему его структурных компонентов, включающую два фрейма «Образование» и «Трудовой путь». В нашем представлении данные информационные блоки подразделяются на фреймовые единицы - терминалы «Детство», «Юность» и соответственно «Начало карьеры», «Профессиональный успех», «Итоги», задающие специфические черты и, в которых сконцентрированы конкретные данные, справедливые для определенной ситуации. Шенк Р. указывает на тождество всех возможных терминалов одного сценария с наиболее типичными для данной ситуации тематическими блоками, наличие которых предполагает оптимальное развитие сценария и адекватное понимание представленной ситуации. [8, с. 90]. В роли конкретных данных выступают слоты, расположенные на нижнем уровне для передачи информации, конкретизируя ту или иную ситуацию.

Анализируемый сценарий «карьера» объективируется в первую очередь фреймом «Образование». Фрейм содержит определенные терминальные данные, позволяющие анализировать глубинную структуру сценария. Входящие в его состав слоты содержат конкретные знания об атрибутах фрейма. По мнению Маминой Т.В., слоты - потенциально возможные вопросы реципиента относительно описываемого явления [4, с. 67]. Исследуемый сценарий развивается таким образом, что структурные элементы фреймовых блоков и заключенной в них терминальной информации, слоты, дублируются от фрейма к фрейму, от терминала к терминалу в силу целенаправленной репрезентации сценария «карьера» на основе совокупных знаний выдающихся представителей русскоязычного мира.

Фрейм «Образование» вербализуется различными синтаксическими связями и лексическими средствами - существительными, глаголами, наречиями, прилагательными, компилирующих исследовательский материал. Данный материал представляет собой фрагмент концептуальной картины мира характерной для представителя русскоязычного населения. Соглашаясь с Ивановой С.В., мы также полагаем, что наш фрейм представляет собой структуру знаний, которая относится к часто происходящим ситуациям, нахо- дящих языковое отражение в лексических связях между глаголами и другими частями речи, а также в синтаксисе сложных синтаксических структур [2, c. 212]. Структурирование фрейма в составе сценария «карьера» мы предлагаем начинать с верхних уровней - терминалов.

Терминалы «Детство» и «Юность» анализируемого фрейма заполнены определенными сведениями о деталях (частностях) - слотами, которые не являются типичными и наличие которых не обязательно в какой-то конкретной ситуации. Терминал «Детство» хранит информацию о первых годах жизни до совершеннолетия, за которым следует период юности, как правило, продолжающийся до 21 года. Специфику развития последнего раскрывает Терминал «Юность», в котором сконцентрированы соответствующие данные. Несмотря на то, что терминалы - стабильные узлы - связаны с хранящейся в них детальной информацией, тем не менее, по мнению Минского М., они могут быть заменены другими сведениями, более подходящими к текущей ситуации, так как связь терминалов с этими данными не является жесткой и неизменной [5, с. 4]. Слотовая наполняемость позволяет на основе частотности употребления лексических единиц языка выявить наиболее типичные для данной ситуации фрагменты действительности.

Анализ практического материала свидетельствует о том, что первый слот «Условия жизни» представлен следующими лексемами: тяжелый (положение, прошлое), приходится (подрабатывать, расстаться, нянчить, пасти), бедность, трудный (жить, привыкнуть, судьба), судьба (сложная, трудная), жить (неплохо, в бедности, трудно, скромно, в нужде), забота (одолевали, заставляли вскакивать по утрам), детство (военное, страшно бедное, счастливое, трудное), школа (не работали, суровую). Данные номинации обладают одной или несколькими словоформами, образующих словоизменительную парадигму:

«Безвыходно тяжелого положения» - Маршал Жуков Г.В.; «С детством пришлось расстаться» - Яшин Л.И.; “Страшно бедное, но все равно счастливое детство» - Кобзон И.Д.; «С трудом вырвался» - Королев С.П.; «Определило мою судьбу» - Кобзон И.Д.; “Жили скромно» - Путин В.В.; «Нас одолевали взрослые заботы» - Яшин Л.И.; «Военное детство»- Кобзон И.Д.; «Школы не работали» - Королев С.П.

Очевидно, что в коллективном русскоязычном сознании фрагмент периода детства, информация о котором сосредоточена в вышеуказанном слоте, отмечен в большинстве случаев пейоративными представлениями, выражающими негативную оценку действительности вследствие историче- 
ских событий на рубеже веков, оказывавших влияние на Россию и последующего участия российского государства в Великой Отечественной войне. Однако мы замечаем в некоторых случаях наличие положительно окрашенных коннотаций: жили не плохо, счастливое детство.

В процессе образования наиболее актуальны этапы обучения, получения и применения знаний. В нашей фреймовой структуре представления знаний данная информация содержится в слоте «Обучение», репрезентируемого лексическими единицами учение (желание продолжать, успешно, сосредотачивался), учить (старался, плохо, прилежно, через пень-колоду, на отлично), отличный (учился, всегда был), школа (забрал документы, пришел поступать, учились в лучших), урок (усердно принялся, готовиться, сказались), заниматься (дома, успешно, самостоятельно) и их словоформами:

"Домашнее учение шло успешно» - Королев С.П.; «Учился на отлично» - Маршал Жуков Г.В.; «Я всегда был отличник» - Кобзон И.Д.; «Бросать школу и браться за домашнее хозяйство» - Маршал Жуков Г.В.; «Усердно готовиться к урокам»-Королев С.П.; «Стал заниматься без троек» - Путин В.В.;

Таким образом, мы видим, что слотовая наполняемость лексическими единицами, которые отражают процесс обучения, создает в сознании реципиента положительный образ. Это объясняется теми временными рамками, в которых находился представитель русскоязычного мира, вынужденный в силу различных обстоятельств не только предпринимать конкретные меры в целях выживания и выбиться в люди, но также идти на определенные жертвы: бросать школу и браться за домашнее хозяйство.

Различные достижения обусловлены не только целенаправленной деятельностью, но также определенными мыслительными процессами, направленными на реализацию сценария по достижению конкретных результатов. Соответствующие данным категориям слот «Мечта» в соотношении с близким в коннотативном смысле слотом «Цель» объективируются посредством лексем мечта (научиться, о побеге, подняться), хотеть (иметь живое дело, учиться), желание (загорелся, возникло), цель (неуклонно шел, поставил) и образованными от них однокоренных слов:

«Мечтал научиться играть на гитаре и выучить английский язык» - Кобзон И.Д.; Очень хотелось учиться в академии» - Королев С.П.; «Возникло желание работать в разведке» - Путин В.В.; «Неуклонно шел к намеченной цели» - Королев С.П.

Каждый ребенок рано или поздно начинает уделять время представлениям, мечтам, в результате ежедневного взаимодействия с окружающим миром.
По мере взросления у него появляются конкретные цели, которых он стремится достичь, складывается мировоззрение и формируется индивидуальная картина мира. Благодаря происходящим мыслительным процессам, мотивирующим субъект, появляется стремление: неуклонно шел, очень хотелось. Данные эмфазы - неуклонно, очень - выражают такие качества характера как целеустремленность, настойчивость, решительность, очевидно, являющиеся характерными для русского сознания.

Информативная наполненность слота «Занятость», добавляет специфичные детали о соответствующей ситуации, актуализируемого при помощи входящих в него лексем заниматься (начал, серьезно, стал, самостоятельно), трудиться (на полевых работах, за нищенскую зарплату), работать (умели, долго, с большим старанием, загружен), служба (был доволен, нести нелегкую, оказалась интереснее), тренировка (тяжело было, регулярные, серьезные), стараться (с большим, хорошо) и их словоформ:

«Начал заниматься в одном из кружков» - Королев С.П.; «Трудились на полевых работах» - Маршал Жуков Г.В.; «Работать умели» - Яшин Л.И.; «Был доволен службой» - Королев С.П.; «Тяжело было на тренировках» - Путин В.В.; «Работал с большим старанием» - Маршал Жуков Г.В.

Основываясь на выделяемых нами лексических номинациях, можно сказать, что рабочий труд в период юности отмечен такими наиболее общими чертами как нелегкий, требующий стараний, что свидетельствует о воздействии исторически сложившихся обстоятельств на ментальность данного языкового сообщества.

Наличие коннотаций «трудные условия» в слоте «Трудности» свидетельствуют о том, что сознание русскозычной личности хранит информацию о приобретенном опыте, заключающемся в столкновении с определенными препятствиями на карьерном пути. Конкретизировать данную ситуацию нам помогают лексемы неудача (постигла, помогал переживать, понесли, снова, опять), уставать (очень, давала о себе знать, чертовски), сложный (оказалась, стало, работать) и следующие словообразования:

«Опять постигла неудача» - Маршал Жуков Г.В.; «Накопившаяся за годы усталость начала давать о себе знать» - Яшин Л.И. «Ситуация оказалась сложннй» - Путин В.B.

Лексико-семантический анализ указывает на то, что в сознании русскоязычного индивида в роли основных противодействующих факторов представляются сложная по характеру работа и снижение эффективности выполнения соответствующих задач на фоне общефизического переутомления и упадка сил. 
Информация, содержащаяся в слоте «Достижения», вербализуемого лексемами успех (освоил, сдав, выдержал), стать (кем-либо), победитель (чего-либо, где-либо), добиваться (с большим трудом, успехов), достигать (результаты), получать (стипендию, рабочую карточку, похвальный лист, специальность), удача (дни), выполняет резюмирующую функцию. Это обусловлено не только наличием соответствующих коннотаций, но также совершенным видом глаголов (стал, получил, добился, выдержал):

«Выдержал успешно» - Маршал Жуков Г.В.;“Стал членом общества» - Королев С.П.; «Был победителем на олимпиадах по художественной самодеятельности» - Кобзон И.Д.; “Добился неплохих успехов» - Путин В.В.; «Успех не был достигнут» - Маршал Жуков Г.В.; "Получил рабочую карточку» Яшин Л.И.; «Случались очень удачные дни» - Маршал Жуков Г.В.

Выделенные лексемы отражают итоги проделанной работы и, несмотря на лексическую вариативность представления этих знаний, мы отмечаем тематическую когерентность элементов дискурса на примере достижения положительного результата. Однако в некоторых случаях основной глагол вступает в связь с другими частями речи, придавая высказыванию противоположное коннотативное значение: не был достигнут, не добившись успеха. Здесь мы подразумеваем отношения между лексическими единицами языка под влиянием грамматических структур на контекстуальный смысл высказывания.

На примере структурирования фрейма «Образование» мы рассмотрели характерный для русского лингвокультурного сообщества сценарий получения образования с последовательно сменяющими друг друга этапами его развития. В анализируемой нами фреймовой структуре динамика развития отображена при переходе от одного этапа (слота) к другому со связывающими их отношениями. Значение компонентов сценария определяется не только социальными, но и культурными факторами. Данный факт свидетельствует о том, что наш сценарий культурологически маркирован, как, например, в стилистически окрашенных словах учение, рабочая карточка, домашнее хозяйство. Поэтому тщательный лексико-семантический анализ позволяет выделить культурную составляющую с целью ее последующего изучения. Результаты подобного исследования представляются особенно важными для проведения лингвокультурологического исследования.

\section{Список литературы:}

1. Жуков Г.К. Воспоминания и размышления. М.: Новости, 1969. 735 с.

2. Иванова С.В. Лингвокультурологический аспект исследования языковых единиц [Электронный ресурс]: Дис... д-ра филол. наук : 10.02.19. Уфа, 2003. 364 с.

3. Кобзон И.Д. Как перед Богом. Изд-во: Известия, 2006. 456 с.

4. Мамина Т.В. Специфика лингвокогнитивного моделирования сценария «карьера» в русском языке: диссертация ... кандидата филологических наук: 10.02.01. Томск, 2011. 225 с.

5. Минский М. Фреймы для представления знаний. М.: Энергия, 1979. 152 с.

6. Ожегов С.И., Шведова Н.Ю. Толковый словарь русского языка Изд-во: М.: ИТИ Технологии; Изд-е 4-е, доп., 2006.944 с.

7. Романов А.П. Королев. М.: Молодая гвардия, 1990. 362 с.

8. Шенк Р. Обработка концептуальной информации / Р. Шенк [и др.]. М., 1980. 361 с.

9. Яшин Л.И. Записки вратаря. М.: Правда, 1976. 64 с.

\section{References (transliterated):}

1. Zhukov G.K. Vospominaniya i razmyshleniya. M.: Novosti, 1969. 735 s.

2. Ivanova S.V. Lingvokul'turologicheskii aspekt issledovaniya yazykovykh edinits [Elektronnyi resurs]: Dis... d-ra filol. nauk : 10.02.19. Ufa, 2003. $364 \mathrm{~s}$.

3. Kobzon I.D. Kak pered Bogom. Izd-vo: Izvestiya, 2006. $456 \mathrm{~s}$.

4. Mamina T.V.Spetsifika lingvokognitivnogo modelirovaniya stsenariya «kar'era» v russkom yazyke: dissertatsiya ...kandidata filologicheskikh nauk: 10.02.01. Tomsk, 2011. $225 \mathrm{~s}$.

5. $\quad$ Minskii M. Freimy dlya predstavleniya znanii. M.: Energiya, 1979. 152 s.

6. Ozhegov S.I., Shvedova N.Yu. Tolkovyi slovar' russkogo yazyka Izd-vo: M.: ITI Tekhnologii; Izd-e 4-e, dop., 2006.944 s.

7. Romanov A.P. Korolev. M.: Molodaya gvardiya, 1990. 362 s.

8. Shenk R. Obrabotka kontseptual'noi informatsii / R. Shenk [i dr.]. M., 1980. 361 s.

9. Yashin L.I. Zapiski vratarya. M.: Pravda, 1976. 64 s. 